\title{
New record of Spotstripe snapper, Lutjanus ophuysenii (Perciformes: Lutjanidae) from Korea
}

\author{
Han Na Kim and Jin-Koo Kim ${ }^{*}$ (D)
}

\begin{abstract}
Three specimens of Lutjanus ophuysenii (217.8-226.7 mm in standard length) were collected by a gill net at Korea between August 2015 and July 2016. This species has not previously been recorded from Korea. L. ophuysenii is very similar to Lutjanus vitta. But several morphological characteristics distinguish the two species, including the number of lateral line scales (46-49 scales in L. ophuysenii; 49-52 scales in L. vitta), a black spot in the middle part of the longitudinal stripe (present in L. ophuysenii; absent in L. vitta), and the absence of a scale on posterior end of the preopercle in L. ophuysenii (present in L. vitta). The Korean name proposed for L. ophuysenii is "Jeom-jul-tung-dom."
\end{abstract}

Keywords: Lutjanus ophuysenii, Lutjanidae, Korean fauna, New record

\section{Background}

The family Lutjanidae in the order Perciformes comprises 17 genera and 185 species worldwide (Nelson 2006), of these, 51 species representing 11 genera occur in Japan (Nakabo 2013) and 14 species representing 6 genera occur in Korea (Kim et al. 2015, 2011, 2007, 2005). Members of the family occur in tropical and subtropical regions of the Pacific, Indian, and Atlantic oceans. And they inhabit the shallow waters around coral reefs to depths of ca. $550 \mathrm{~m}$. The genus Lutjanus occur in the Yellow Sea, the southern East Sea, and the Pacific and Indian oceans. Chyung (1977) and Kim et al. (2005) made morphological description of four species of the genus Lutjanus in Korea: Lutjanus rivulatus (Cuvier 1828), Lutjanus vitta (Quoy and Gaimard 1824), Lutjanus monostigma (Cuvier 1828), and Lutjanus russelli (Bleeker 1849). Recently, Kim et al. (2007) and Kim et al. (2012) reported the occurrence of five species previously unrecorded in Korea: Lutjanus argentimaculatus (Forsskål 1775), Lutjanus fulviflamma (Forsskål 1775), Lutjanus quinquelineatus (Bloch 1790), Lutjanus malabaricus (Schneider 1801), and Lutjanus stellatus (Akazaki 1983).

Three specimens representing the genus Lutjanus were collected in a gill net from Korea between August

\footnotetext{
* Correspondence: taengko@hanmail.net

Department of Marine Biology, Pukyong National University, Busan 48513, Korea
}

(c) The Author(s). 2016 Open Access This article is distributed under the terms of the Creative Commons Attribution 4.0 International License (http://creativecommons.org/licenses/by/4.0/), which permits unrestricted use, distribution, and reproduction in any medium, provided you give appropriate credit to the original author(s) and the source, provide a link to the Creative Commons license, and indicate if changes were made. The Creative Commons Public Domain Dedication waiver (http://creativecommons.org/publicdomain/zero/1.0/) applies to the data made available in this article, unless otherwise stated.

\section{Methods}

Three specimens collected in Korea between August 2015 and July 2016 were identified as L. ophuysenii (Fig. 1). The specimens were fixed in $10 \%$ formalin and then in $70 \%$ ethanol. Methods for making counts and measurements followed Allen and Talbot (1985) and Hubbs and Lagler (2004), with measurements performed to the nearest $0.1 \mathrm{~mm}$ by a Vernier caliper. Vertebrae were counted from radiographs (Softex HA-100, Japan). The specimens were stored at Pukyong National University (PKU 13174 and PKU 58149) and Marine Biodiversity of Korea (MABIK PI-00045859).

Genomic DNA was extracted from muscle tissue using Chelex 100 resin (Bio-Rad, Hercules, CA, USA). The polymerase chain reaction (PCR) was made by the universal primer VF2 (5-TCAACCAACCACAAAGACA TTGGCAC-3) and FishR2 (5-ACTTCAGGGTGACCGA 


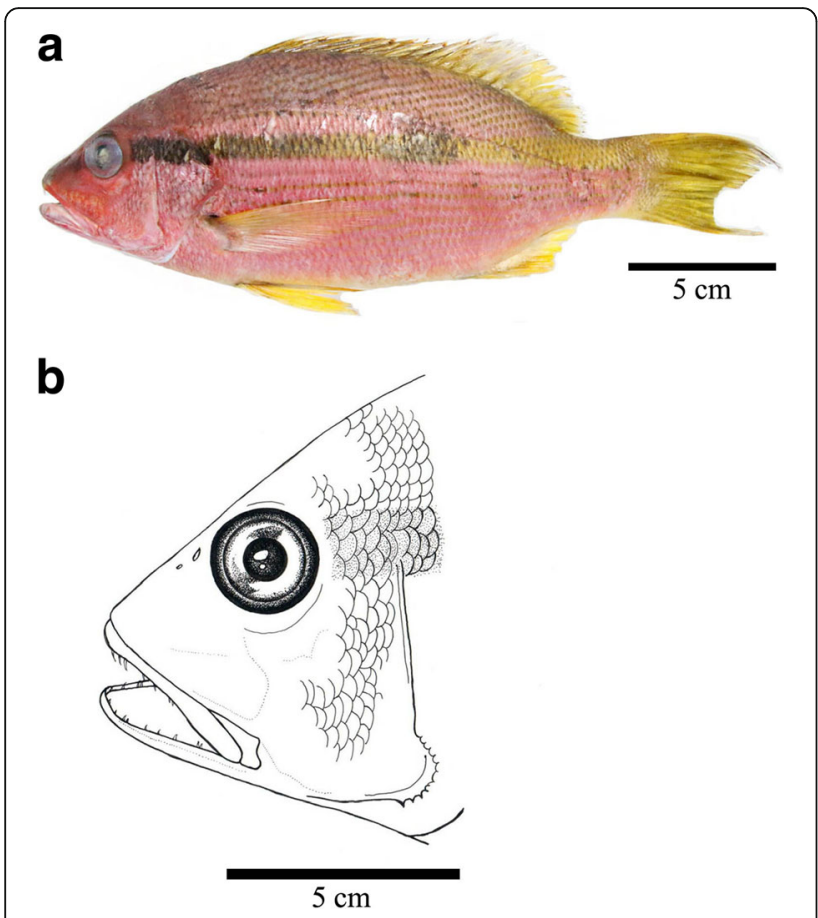

Fig. 1 Photo and illustration of Lutjanus ophuysenii. a Lutjanus ophuysenii, PKU 13174, 217.8 mm SL, Gadeok-do, Busan, Korea. b Head of Lutjanus ophuysenii (PKU 13174) showing the cheek scale distribution

AGAATCAGAA-3) to amplify the mitochondrial DNA cytochrome $c$ oxidase subunit I (COI) (Ivanova et al. 2007; Ward et al. 2005). The condition of PCR, purification of PCR products, and sequencing were followed by the method of Ji et al. (2016). The sequences were aligned using ClustalW (Thompson et al. 1994) in BioEdit version 7 (Hall 1999). Comparisons were conducted using the sequences of six species of the genus Lutjanus in the National Center for Biological Information database: L. vitta (KP194726, KC970486, JN208424), L. ophuysenii (LC085448), L. monostigma (JQ350098, JQ350096, JQ350095), L. fulviflamma (KP194911, KP194573, KP194190), L. quinquelineatus (KP009621, KF714960, KF009620), and L. argentimaculatus (KP194776, KF714960, KF714959). Genetic distances were calculated by the Kimura-2-parameter model (Kimura 1980) in MEGA 5 (Tamura et al. 2011).

\section{Results and discussion}

\section{Lutjanus ophuysenii (Bleeker 1860)}

(Korean name: Jeom-jul-tung-dom) (Fig. 1)

Mesoprion ophuysenii: Bleeker, 1860: 74 (type locality: Benkulen, Sumatra, Indonesia; Nagasaki, Japan)

L. ophuysenii: Iwatsuki et al. 1993: 48 (Japan); Lee and Cheng 1996: 340 (Taiwan); Sadovy and Cornish 2000: 121 (Hong Kong); Shimizu 2001: 30 (Japan); Nakabo and Shimada 2013: 918 (Japan)

\section{Material examined}

PKU 13174, 1 specimen, $217.8 \mathrm{~mm}$ SL, Gadeock-do, Busan, Korea, 3 August 2015, collected by Jin-Koo Kim and Woojun Lee; PKU 58149, 1 specimen, $218.5 \mathrm{~mm}$ SL, Pohang, Gyeongsangbuk-do, Korea, 19 July 2016, collected by Seoknam Kwak; MABIK PI-00045859 (formerly PKU 55757), 1 specimen, $226.7 \mathrm{~mm} \mathrm{SL}$, Gadeock-do, Busan, Korea, 7 September 2015, collected by Jin-Koo Kim and Woojun Lee.

\section{Description}

Dorsal fin rays $\mathrm{X}, 13$; anal fin rays III, 8; pectoral fin rays 15-16; lateral line scales 47-48; horizontal scale rows above and below lateral line scales 8 and 15-17, respectively; scale rows on cheek 6; total gill rakers on first gill arch $7+13-14$; body depth $2.76-2.9$; head length $2.67-$ 2.95 , both in SL; snout length 2.81-3.07; eye diameter 4.5-4.72; interorbital distance 3.47-3.74; maxillary length 2.22-2.4; preorbital depth 3.69-3.95, all in head length (Table 1).

Body slightly oval; head and tail moderately compressed; line connecting mouth and dorsal pin origin gradual; eyes large (21.1-21.9\% of head length) and rounded, located above posterior margin of upper jaw; upper jaw similar in length to lower jaw; mouth pointed; single row of conical and curved teeth in each jaw; upper teeth larger than lower teeth; vomerine teeth arrowshaped; two pairs of nostrils, located in front of the eye; anterior nostril slightly long and oval; posterior nostril round; notch on posterior margin of preopercle shallow; small spine on posterior end of preopercle; preopercle covered with scales, except for posterior end; body covered with ctenoid scales; base of dorsal and anal soft ray, pectoral, and caudal fin covered with scales; caudal fin slightly emarginated.

\section{Coloration}

When fresh, generally light reddish; all fins yellowish; a number of oblique brown stripes above lateral line; anterior margin of stripe parallel with lateral line; longitudinal band extending from the eye to caudal peduncle; posterior margin of longitudinal band faint; black spot on middle part of longitudinal band; a number of straight lines below longitudinal band.

Generally yellowish (including all fins) following fixation in formalin; brown oblique stripe above lateral line; longitudinal band on center of body; black spot on middle part of longitudinal band; a number of straight lines below longitudinal band; ventral margin of straight line not clear.

\section{Distribution}

Korea Strait, southern Korea (the present study); southern Japan (Iwatsuki et al. 1993); western part of Taiwan (Lee 
Table 1 Comparison of morphological characters of Lutjanus ophuysenii

\begin{tabular}{|c|c|c|c|c|c|}
\hline \multirow{2}{*}{$\begin{array}{l}\text { Morphological } \\
\text { characters }\end{array}$} & \multicolumn{5}{|c|}{ Lutjanus ophuysenii } \\
\hline & Present study & Bleeker (1860) & Iwatsuki et al. (1993) & Lee and Cheng (1996) & Shimada (2013) \\
\hline Number of specimens & 3 & - & 42 & 25 & - \\
\hline Standard length (mm) & $217.8-226.7$ & - & $56.5-337.5$ & $182-256$ & - \\
\hline \multicolumn{6}{|l|}{ Counts } \\
\hline Dorsal fin rays & $x, 13$ & $x, 13$ & $X, 12-13$ & $X, 12-13$ & $x, 12-13$ \\
\hline Anal fin rays & III, 8 & III, 8 & III, 8 & III, 8 & III, 8 \\
\hline Pectoral rays & $15-16$ & 16 & $16-17$ & - & $16-17$ \\
\hline Lateral line scales & $47-48$ & - & $46-49$ & $47-49$ & $46-49$ \\
\hline Gill rakers & $7+13-14$ & - & $6-7+13-16$ & $7-8+7-13$ & - \\
\hline Vertebrae & 23 & - & - & - & - \\
\hline \multicolumn{6}{|l|}{ Standard length } \\
\hline Body depth & $2.76-2.95$ & - & $2.12-3.17$ & - & - \\
\hline Head length & $2.67-2.81$ & - & $2.15-3.31$ & - & - \\
\hline \multicolumn{6}{|l|}{ Head length } \\
\hline Eye diameter & $4.5-5.11$ & - & $3.38-5.74$ & - & - \\
\hline Snout length & $2.89-3.07$ & - & $2.78-3.70$ & - & - \\
\hline Interorbital width & $3.48-3.74$ & - & $3.57-5.72$ & - & - \\
\hline Maxillary length & $2.22-2.4$ & - & $2.07-2.82$ & - & - \\
\hline Preorbital depth & 3.69-3.95 & - & $4.3-7.5$ & $4.61-7.52$ & - \\
\hline
\end{tabular}

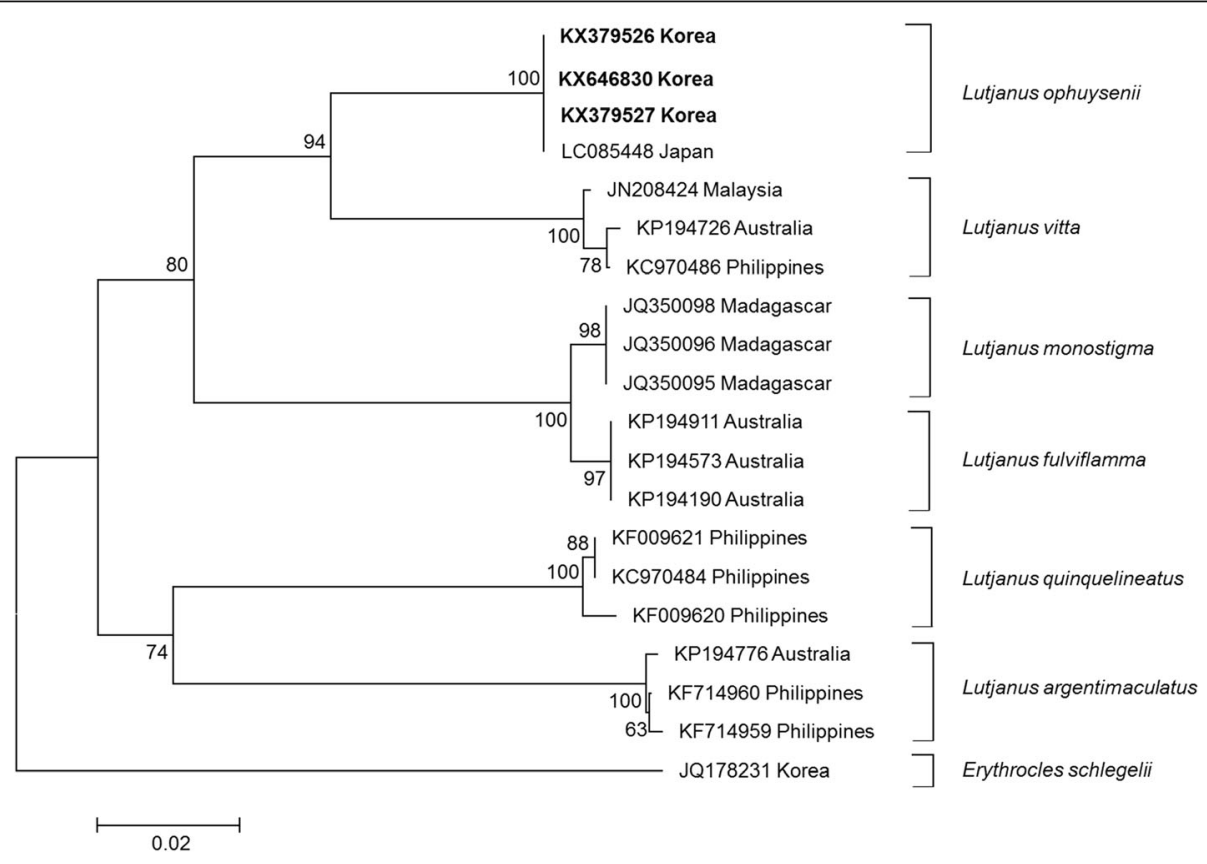

Fig. 2 Neighbor joining tree showing the relationships among six species of the genus Lutjanus including Lutjanus ophuysenii (three Korean specimens and one Japanese specimen). Erythrocles schlegelii was included as an outgroup. Numbers at branches indicate bootstrap probabilities based on 10,000 bootstrap replications. The bar indicates a genetic distance of 0.02 
Table 2 Comparison of morphological characters between Lutjanus ophuysenii and Lutjanus vitta

\begin{tabular}{|c|c|c|c|c|}
\hline \multirow{2}{*}{$\begin{array}{l}\text { Morphological } \\
\text { characters }\end{array}$} & \multicolumn{2}{|l|}{ L. ophuysenii } & \multicolumn{2}{|l|}{ L. vitta } \\
\hline & Present stud & & Chyung (1977) & Iwatsuki et al. (1993) \\
\hline Voucher number & PKU 13174 & PKU 55759 & & \\
\hline Standard length $(\mathrm{mm})$ & 217.8 & 226.7 & & $70.0-230.0$ \\
\hline \multicolumn{5}{|l|}{ Counts } \\
\hline Dorsal fin rays & $x, 13$ & $x, 13$ & $x, 13$ & $X, 12-13$ \\
\hline Anal fin rays & III, 8 & III, 8 & III, 7-8 & III, 8 \\
\hline Pectoral fin rays & 16 & 15 & $16-17$ & $16-17$ \\
\hline Lateral line scales & 47 & 48 & $49-53$ & $49-52$ \\
\hline Gill rakers & $7+13$ & $7+14$ & $17-22$ & $6-8+10-15$ \\
\hline Vertebrae & 23 & 23 & - & - \\
\hline
\end{tabular}

and Cheng 1996); Hong Kong (Sadovy and Cornish 2000); South China Sea (Wang et al. 2010).

\section{Remarks}

Three specimens collected from Busan, Korea, were identified as L. ophuysenii, on the basis of the following characteristics: dorsal fin rays X, 13; anal fin rays III, 8; vomerine teeth arrow-shaped; and black spot on the middle part of longitudinal stripe (Table 1). Most measurements and morphological characteristics were consistent with the original description (Bleeker 1860) and other studies (Shimada 2013; Lee and Cheng 1996; Iwatsuki et al. 1993), but different slightly from that of Iwatsuki et al. (1993) with respect to eye diameter and from those of Iwatsuki et al. (1993) and Lee and Cheng (1996) with respect to the preorbital depth. These morphometric differences seem to represent intraspecific variation from the viewpoint of their genetic correspondence (Fig. 2).

Because L. ophuysenii is very similar to L. vitta, Allen and Talbot (1985) considered that they were the same species. However, Iwatsuki et al. (1993) proposed taxonomic characteristics that can distinguish the two species. Our specimens were distinguished from L. vitta by the number of lateral line scales (46-49 in L. ophuysenii, 49-52 in L. vitta), the occurrence of a black spot at the middle part of the longitudinal stripe (present in L.ophuysenii, absent in L. vitta), and the occurrence of a scale at the posterior end of the preopercle (absent in $L$. ophuysenii, present in L. vitta) (Table 2). In addition, the two species have different distribution ranges (southern East Sea, East China Sea, and Yellow Sea for L. ophuysenii, but southern Ryukyu Island, Taiwan, and the Indo-West Pacific for L.vitta) (Iwatsuki et al. 1993). L. vitta was first reported in Korea by Chyung (1977), being inconsistent with the distribution of $L$. vitta already mentioned by Iwatsuki et al. (1993). The illustrations and descriptions of Chyung's (1977) L. vitta, such as the absence of a spot on the longitudinal stripe and the number of lateral line scales (49-53), confirm that the species reported by
Chyung (1997) is L. vitta. However, detailed distribution range of this species will be required for the further research.

To identify the two specimens genetically in detail, we analyzed 479 base pairs of the mitochondrial DNA COI gene. The DNA sequences corresponded to those of $L$. ophuysenii from Japan (LC085448) and considerably differed from those of L. vitta $(d=0.066-0.071)$. Thus, the three specimens in the present study were identified as L. ophuysenii using both morphological and molecular methods (Fig. 2). We propose the Korean name "Jeom-jultung-dom" for L. ophuysenii in having a distinct black spot at the middle part of the longitudinal stripe.

\section{Conclusion}

Three specimens of the genus Lutjanus collected from Korea between August 2015 and July 2016 were identified as L. ophuysenii in having 46-49 lateral line scales, a distinct black spot at the middle part of the longitudinal stripe, and a scale at the posterior end of the preopercle. An analysis of 479 base pairs of the mitochondrial DNA COI gene showed that sequences corresponded to those of L. ophuysenii from Japan.

\section{Abbreviations}

COI: Cytochrome c oxidase subunit 1; d: Genetic distance; PCR: Polymerase chain reaction

\section{Acknowledgements}

This research was supported by the Marine Fish Resources Bank of Korea (MFRBK) under the Ministry of Oceans and Fisheries, Korea.

\section{Funding}

This work was supported by Marine Fish Resource Bank of Korea (MFRBK).

\section{Availability of data and materials}

All datasets analyzed during the current study are available from the corresponding author on reasonable request.

\section{Authors' contributions}

HNK performed the experiments and wrote the manuscript. JKK suggested all the aspects of the study design and commented on the earlier drafts of the manuscript. Both authors read and approved the final manuscript. 


\section{Competing interests}

The authors declare that they have no competing interests.

\section{Consent for publication}

Not applicable.

\section{Ethics approval and consent to participate}

Not applicable.

Received: 12 August 2016 Accepted: 2 December 2016

Published online: 12 December 2016

\section{References}

Allen GR, Talbot FH. Review of the snappers of the genus Lutjanus (Pisces: Lutjanidae) from the Indo-Pacific, with the description of a new species. Indo-Pac Fishes. 1985;11:76-7.

Bleeker P. Achtste bijdrage tot de kennis der vischfauna van Sumatra (Visschen van Benkoelen, Priaman, Tandjong, Palembang en Djambi). Acta Societatis Regiae Scientiarum Indo-Neêrlandicae. 1860;8:1-88.

Chyung MK. The fishes of Korea. Seoul: Ilchisa; 1977. p. 317-36.

Hall TA. BioEdit: a user-friendly biological sequence alignment editor and analysis program for Windows 95/98/NT. Nucleic Acids Symp Ser. 1999;41:95-8.

Hubbs CL, Lagler KF. Fishes of the Great Lakes region. Revisedth ed. Ann Arbor: University of Michigan Press; 2004. p. 332.

Ivanova NV, Zemlak TS, Hanner RH, Hebert PDN. Universal primer cocktails for fish DNA barcoding. Mol Ecol Notes. 2007;7:544-8. http://dx.doi.org/ 10.1111/j.1471-8286.2007.01748.x.

Iwatsuki Y, Akazaki M, Yoshino T. Validity of a lutjanid fish, Lutjanus ophuysenii (Bleeker) with a related species, L. vitta (Quoy et Gaimard). Japan J Ichthyol. 1993:40:47-59.

Ji HS, Kim JK, Kim BJ. Molecular phylogeny of the families Pleuronectidae and Poecilopsettidae (PISCES, Pleuronectiformes) from Korea, with a proposal for a new classification. Ocean Sci J. 2016;51:299-304. http://dx.doi.org/10.1007/ s12601-016-0026-8.

Kim IS, Choi Y, Lee CL, Lee YJ, Kim BJ, Kim JH. Illustratied book of Korean fishes. Seoul: Kyohak Publishing Co; 2005. p. 320-2.

Kim BJ, Nakaya K, Endo H. Three juvenile snappers of the genus Lutjanus (Perciformes Lutjanidae) collected from Jeju Island, Korea. J Fish Sci Technol. 2007;10:68-73.

Kim JS, Kim BY, Song CB. First record of the green jobfish, Aprion virescens (Perciformes: Lutjanidae) from Korea. Korean J Ichthyol. 2011;23:310-3.

Kim MJ, Kim BY, Kim JS, Song CB. Two unrecorded species of the snapper (Perciformes: Lutjanidae) collected from Jeju Island. Korea Fish Aquat Sci. 2012;15:313-6. http://dx.doi.org/10.5657/FAS.2012.0313.

Kim MJ, Mun TS, Lee JH, Choi YM, Song CB. New record of the chinamanfish, Symphorus nematophorus (Perciformes: Lutjanidae) from Korea. Korean J Ichthyol. 2015;27:149-52.

Kimura M. A simple method for estimating evolutionary rates of base substitutions through comparative studies of nucleotide sequences. J Mol Evol. 1980;16:111-20. http://dx.doi.org/10.1007/BF01731581.

Lee SC, Cheng HL. Genetic difference between two snappers, Lutjanus ophuysenii and L. vitta (Teleostei: Lutjanidae). Ichthyol Res. 1996;43:340-4.

Nakabo T, Shimada K. Lutjanidae. In: Fishes of Japan with pictorial keys to the species. Thirdth ed. Tokyo: Tokai Univ Press; 2013. p. 819-32.

Nelson JS. Fishes of the World. 4th ed. Hoboken: John Wiley \& Sons, Inc; 2006. p. 366

Sadovy Y, Cornish AS. Reef fishes of Hong Kong. Hong Kong Univ Press; 2000. p. $1-321$

Shimizu T. An annotated list of the coastal fishes from lyo city, Ehime Prefecture, Japan. Bull Tokushima Prefectural Mus. 2001;11:17-99. http://dx.doi.org/10. 1007/BF02347607.

Tamura K, Peterson D, Peterson N, Stecher G, Nei M, Kumar S. MEGA5: molecular evolutionary genetics analysis using maximum likelihood, evolutionary distance, and maximum parsimony methods. Mol Biol Evol. 2011;28:2731-9. http://dx.doi.org/10.1093/molbev/msr121.

Thompson JD, Higgins DG, Gibson TJ. CLUSTAL W: improving the sensitivity of progressive multiple sequence alignment through sequence weighting, position-specific gap penalties and weight matrix choice. Nucleic Acids Res. 1994;22:4673-80. http://dx.doi.org/10.1093/nar/22.22.4673.
Wang ZD, Guo YS, Tan W, Li L, Tang EP, Liu CW, Liu Y. DNA barcoding, phylogenetic relationships and speciation of snappers (genus Lutjanus). Sci China Life Sci. 2010;53:1025-30. http://dx.doi.org/10.1007/s11427-010-4034-0. First Record of the Green Jobfish, Aprion virescens (Perciformes: Lutjanidae) from Korea.

Ward RD, Zemlac TC, Innes BH, Last PR, Hebert PDN. DNA barcoding Australia's fish species. Philos Trans Biol Sci. 2005;360:1847-57.

\section{Submit your next manuscript to BioMed Central and we will help you at every step:}

- We accept pre-submission inquiries

- Our selector tool helps you to find the most relevant journal

- We provide round the clock customer support

- Convenient online submission

- Thorough peer review

- Inclusion in PubMed and all major indexing services

- Maximum visibility for your research

Submit your manuscript at www.biomedcentral.com/submit
) Biomed Central 